\title{
A recepção de Malhação e o cotidiano de prováveis extensionistas rurais em formação
}

Paulo de Jesus

Doutor em Ciências da Educação (Université Paris VIII) e professor da UFRPE - Universidade Federal Rural de Pernambuco.

E-mail: paulodej@terra.com.br

Nara Silvana Albuquerque Patriota

Mestra em Extensão Rural e Desenvolvimento Local - POSMEX

pela Universidade Federal Rural de Pernambuco e professora no

Colégio Agrícola Dom Agostinho Ikas - CODAI (PE).

E-mail: n_patriota@hotmail.com

Resumo: Este texto trata de alguns pressupostos teóricos e resultados parciais de uma pesquisa empírica com jovens, na perspectiva de um estudo de recepção com estudantes do curso de formação profissional de nível médio, Técnico em Agropecuária (TA), do Colégio Agrícola Dom Agostinho lkas, São Lourenço da Mata (PE). A preocupação é analisar como os estudantes de cursos agrários ressignificam as mensagens urbanas, veiculadas pela ficção televisiva da telenovela Malhação, e se, de alguma forma, essas mensagens exercem influência no cotidiano desses prováveis extensionistas rurais. Recorreu-se a, entre outros, Martín-Barbero, Guilhermo Orozco e Maria Lourdes Motter, num esforço de diálogo diante dos dados empíricos produzidos. As análises evidenciam que as mensagens interferem de maneira relativa no cotidiano dos estudantes, mediatizados por diversos grupos sociais que propiciam aproximações, negociações e rejeições do urbano com o rural.

Palavras-chave: comunicação e educação, estudo de recepção, telenovela Malhação, extensionistas.
Abstract: This text deals about some theoretical and research partial results from an empirical research with young people, in a perspective of a joint reception study along with students of the average level course of Professional Formation - Farming Technician (FT) of the Dom Augustin Ikas Agricultural College, in São Lourenço da Mata in Pernambuco State. The concern is to analyze, in the reception space how the agrarian course students mean again the urban messages, spread by television soap opera Malhação and if, in some way, these messages exert any influence in the day by day of these probable agricultural extent. It was appealed, among others, to Martín-Barbero, Guilhermo Orozco, Maria de Lourdes Motter, in a dialogue effort facing the produced empirical data. The analysis, shows that the messages interferes in a relative way in the students day by day, mediate by several social groups that propitiate approximation, negotiations and rejections from urban and rural.

Keywords: communication and education, reception study, soap opera exercising, extension.
Recebido: 30/08/2006 Aprovado: 16/02/2007 
1. CARNEIRO, Maria José

O ideal urbano: campo e cidade no imaginário dos jovens rurais. In: SILVA Francisco Carlos Teixeira da; SANTOS, Raimundo CARVALHO COSTA, Luiz Flávio de (Orgs.). Mundo rural e política: ensaios interdisciplinares. Rio de Janeiro: Ed. Campos Pronex, 1999. p 1-19; MORAES, Gilberto. A moderna agropecuária. 2. ed. Porto Alegre: Sagra, 1993. p. 84-85.
Este texto é resultado da pesquisa sobre a telenovela Malhação e o cotidiano de prováveis extensionistas rurais sobre telenovela, no qual se procurou investigar de que maneira as mensagens recebidas da mídia televisiva, através da telenovela em questão, exibida pela Rede Globo, interferem no cotidiano dos estudantes do Curso Técnico em Agropecuária (TA) do Colégio Agrícola Dom Agostinho Ikas - CODAI, em São Lourenço da Mata (PE), no que se refere à família, à formação profissional e ao trabalho nas suas práticas cotidianas. Especificamente, interessa-nos compreender como esse jovem em processo de formação escolar, voltada para a atividade agropecuária, está se apropriando de conteúdos, predominantemente urbanos, exibidos em Malhação, que interferências têm essas mensagens no seu cotidiano e como essa telenovela sugere uma aproximação ou não das aspirações desses jovens com a área agropecuária do seu dia-a-dia na escola, reurbanizando ${ }^{1}$ as mensagens.

O objetivo da pesquisa centrou-se em investigar como acontece a comunicação entre as mensagens veiculadas pela ficção, apresentadas no âmbito urbano, e a realidade dos jovens em processo de formação escolar, cujas informações estão voltadas às questões agrárias.

\section{A TRAJETÓRIA DA PESQUISA}

Para fazer parte desta pesquisa, foram selecionadas oito turmas do curso Técnico em Agropecuária do CODAI. Nessa primeira parte entregou-se um questionário exploratório a 109 estudantes, com a intenção de identificar aqueles que assistiam à Malhação com certa assiduidade. Foram devolvidos 47. Desses, 23 participaram da segunda parte - as sessões de recepção da pesquisa, que ocorreu em outubro e novembro de 2003. Na terceira e última parte, foi distribuído um questionário com 38 perguntas semi-abertas, 25 sobre o jovem e sua família, e 13 sobre a escola e os interesses profissionais.

Realizaram-se 24 sessões, quatro por semana, com a seguinte dinâmica, projeção e discussão.

Nas citações dos extratos das entrevistas, optou-se pela preservação das identidades dos entrevistados, mediante o uso de duas letras de seus nomes seguido do número da página do Caderno de entrevistas. Para o estudo, elegeuse o episódio intitulado "Destinos cruzados", levado ao ar de 28/04/2003 até 18/01/2004. Dele foram retiradas 42 cenas, exibidas em 6 semanas. A escolha desse episódio foi fomentada pela relação interior/cidade que a telenovela apresentava através da personagem vilã Carla, uma jovem vinda do interior.

Quanto à análise, ela se processou em três etapas: na primeira, mapearam-se as categorias nos textos da entrevista; na segunda, elaboraram-se textos temáticos e derivados das categorias com as falas dos participantes/estudantes. Na análise propriamente dita, ou terceira etapa, estabeleceram-se relações entre as falas dos participantes (textos temáticos), o problema de pesquisa e seus objetivos e o pensamento de alguns autores. 


\section{DIÁLOGO ENTRE OS EMISSORES FICCIONAIS E RECEPTORES REAIS}

No bojo da relação entre o simbólico e o real, na busca por essa hegemonia, constrói-se, segundo Baccega, "o campo da comunicação/educação"?.

A comunicação/educação é um espaço teórico que hoje se fundamenta nas práticas de formação de sujeitos conscientes; entretanto, é pertinente compreender a complexidade da educação na atualidade, diante dos meios de comunicação de massa que se apresentam como um outro lugar que, para Barbero $^{3}$, faz parte ativamente do cotidiano das pessoas, principalmente dos jovens, atuando, com a escola, a família e a religião, na maneira como estes estão se vendo e como se relacionam com os outros nessa nova sociedade: "...um mundo individual onde os discursos se cruzam, se agrupam, se esbarram e se completam...". E, dessa interação, nascem novos discursos com novas formas de sentir, interpretar e ler os diálogos de todos os discursos sociais nessas relações que o jovem estabelece.

\section{A TELENOVELA NO COTIDIANO DOS JOVENS}

Para alguns pesquisadores desse gênero ficcional, como Marcondes Filho ${ }^{5}$, Maria Lourdes Motter ${ }^{6}$, Nora Mazziotti, Gerlinde Frey-Vor ${ }^{7}$, Maria de Fátima Faila Elias $^{8}$ e Maria Ataíde Malcher ${ }^{9}$, esse horário vespertino de programação se dá pelo fato de as pessoas cultivarem alguns desejos de mudanças em sua vidas, direcionadas para o campo da emoção. Para Elias, "a telenovela possibilita ao telespectador uma identificação com o seu cotidiano como espelho da realidade $[\ldots]$ parece colocar um pouco de fantasia na vida real e um pouco de realidade na fantasia" 10 .

\section{A RECEPÇÃO DE MALHAÇÃO: ANÁLISE DAS MENSAGENS}

Nessa conjuntura de análise, observou-se que as famílias, tanto ficcionais como reais, experimentam muitas dificuldades de relacionamento; de um lado, os pais (adultos, experientes e preocupados com o futuro) e, de outro, os filhos (jovens, sonhadores e ansiosos por vivenciar novas sensações e situações). $M a$ lhação, portanto, traz à tona esse relacionamento conflituoso entre o jovem e o adulto e as experiências de ambos no cotidiano ficcional, num viés voltado para questões de comportamento e valores éticos e profissionais, o que favorece a sua disseminação entre os adultos e pais de adolescentes. Alguns temas, como impor limites aos filhos e invadir a privacidade dos mesmos, aconselhar sobre questões pessoais como namoro, casamento e a formação profissional, foram abordados pela telenovela no período da pesquisa e escolhidos para este estudo e análise. Quando indagamos sobre o relacionamento dos jovens reais com suas famílias, obtivemos de alguns entrevistados respostas que evidenciam a ambigüidade em que eles se encontram, principalmente sobre limites e diálogo:
2. BACCEGA, M. A. Da comunicação à comunicação/educação. Comunicação \& Educação, São Paulo: CCA-ECA-USP/ Segmento, ano VII, n. 21, p. 7-16, maio/ago. 2001.

3. MARTÍN-BARBERO, J. Dos meios às mediações: comunicação, cultura e hegemonia. Rio de Janeiro: UFRJ, 1997.

4. Ibid.

5. MARCONDES FILHO, C. Televisão. São Paulo: Scipione, 1994. Id. Televisão: a vida pelo vídeo. São Paulo: Moderna, 1988.

6. MOTTER, M. L. Telenovela: a arte do cotidiano. Comunicação \& Educação, São Paulo: CCA-ECA-USP/Moderna, n. 13 , p. 89-102, set./dez. 1998. Id. Telenovela e educação: um processo interativo. Comunicação \& Educação, São Paulo: CCA-ECA-USP/Segmento, n. 17, p. $54-60$, jan./abr. 2000. Id. Ficção e realidade: a construção do cotidiano na telenovela. São Paulo: Alexia Cultural, 2003. Id. Mecanismos de renovação do gênero telenovela: empréstimos e doações. In: LOPES, M. I. V. (Org.). Telenovela, internacionalização e interculturalidade. São Paulo: Loyola, 2004.

7. MAZZIOTTI, N.; FREYVOR, G. Telenovela e soap opera. Comunicação \& Educação, São Paulo: CCA-ECA-USP/ Moderna, n. 6, p. 47-57, maio/ago. 1996.

8. ELIAS, M. F. F. O adolescente diante da novela. Comunicação \& Educação, São Paulo: CCA-ECAUSP/Moderna, n. 11, p. 35-47, jan./abr. 1998.

9. MALCHER, M. A. A memória da telenovela: legitimação e gerenciamento. São Paulo: Alexa Cultural, 2003.

10. ELIAS, O adolescente..., op. cit., p. 35. 
comunicação \& educação • Ano XIII • Número 2 - maio/ago 2008

Os pais querem sempre proteger os filhos, mas têm que saber que eles têm que passar por determinadas coisas para se tornar independentes (JU, p. 140).

Eu acho que o adolescente é muito impulsivo e acha que consegue resolver tudo sozinho (BA, p. 1).

E, hoje, eu agradeço a Deus minha mãe não ter dado o limite que eu queria; ela me deu limite, mas com responsabilidade (MP, p. 271).

[...] porque tem uma coisa que a gente quer fazer que os pais não deixam, e, às vezes, tem isso também, eles tudo são contrário; a gente tem consciência que certos atos tá certo; eles acham que a gente quer fazer coisas demais... têm que ver o nosso lado também, mas é muito chato ( $\mathrm{D}, \mathrm{p} .18)$.

[...] se a gente tem pai, temos que sugar o máximo da sabedoria deles, pra chegar lá em cima, mais na frente, sem tanto machucado (AD, p. 14).

Sobre a maneira tranqüila como a telenovela apresenta a solução de um problema que envolve os jovens e vícios, para os estudantes foi simples demais, muito diferente daquela que eles vêem no seu cotidiano:

Ah! Aí é o modelo de superpai, todo mundo entende tudo, todo mundo é bonzinho, não mostra o cara discutindo dentro de casa, não mostra essas pequenas coisas da vida das pessoas (AD, p. 14).

E a vida não é assim, né? (MA, p. 14).

Meu pai e minha mãe ficam em cima direto... Se ele achar que alguém que eu ando assim for estranho, eles já reclamam. [...] Porque nesse mundo tem de tudo agora, porque a gente conhece quem usa droga e quem não usa (ED, p. 157-158).

Para outros, a diferença está no diálogo:

Se você não tiver uma boa preparação em casa, assim, informações dos pais sentarem e conversarem, você cai fácil, fácil (MA, p. 112).

[...] mas acho também que é porque não tem aquele diálogo antes de acontecer as coisas, aí o problema é depois, quando já está fumando. Acho que deveria falar antes... lá em casa mesmo não existe o diálogo. Mas acho que acontece (PR, p. 95).

Com relação à maneira diferenciada de os pais tratarem o filho ou a filha:

Este cuidado acho mais normal com a menina do que com menino. Na verdade, filho é filho (HE, p. 86-87).

A sociedade é machista, então isso já está entranhado, não vai tirar assim de uma hora pra outra (ED, p 260).

Para as meninas é uma questão de machismo: a filha é sufocada. [...] Eles prendem mais as filhas do que os homens. Eu acho que o mundo ainda, infelizmente, é muito machista (MA, p. 109-111).

Sobre a mãe invadir a privacidade, como aconteceu na telenovela, os estudantes afirmam não gostar dessa atitude, mas tentam compreender isso como uma forma de ela obter informações por eles negadas, ou como simples curiosidade: 
Acho que é normal até um certo limite... desse jeito que ela está não é mais normal (ED, p. 89).

Minha mãe mexe nas minhas coisas e eu nem ligo; minha mãe olha minha bolsa e eu nem ligo; eu deixo minha carteira e ela olha minha carteira (JH, p. 62).

Mesmo sem querer, dá uma olhadinha. Assim, curiosamente. Só por curiosidade (DU, p. 62).

Alguns se revelaram incomodados com essa atitude da mãe:

"É chato ficar se metendo na privacidade das pessoas" (JU, p. 74).

A mãe... vasculha, procura saber. Eu já me incomodei, assim, às vezes a gente se incomoda, porque, querendo ou não, quebra a privacidade da pessoa; mas, por outro lado, é bom porque quem está de fora é mais fácil de ver, de dar conselho... (MP, passim, passim).

O episódio selecionado para a pesquisa faz referências ao rural, mas o discurso das personagens só favorece antigos paradigmas, veiculando ainda o rural à idéia de atraso, que pode acentuar a dicotomia entre rural e urbano no imaginário dos jovens estudantes do CODAI, apesar dos recentes estudos sobre o Novo rural brasileiro ${ }^{11}$, o Desenvolvimento sustentável ${ }^{12}$ e a Educação $^{2}$ básica para o campo $^{13}$.

Sobre essa representação do rural na telenovela, alguns estudantes revelaram a sua importância para a cidade:

[...] é importante a área agrária; mesmo que a pessoa não queira, é muito importante, porque é onde tudo começou, é a origem de tudo [...] o homem não pode esquecer dessa origem, porque a cidade não pode viver sem o campo, mas o campo pode viver sem a cidade [...] ela [Malhação] só mostra assim o pessoal que veio do interior para a cidade grande, pra se dar bem. Mostra mais o êxodo rural, que o campo não tem ninguém e é todo mundo vindo para a cidade (DA, p. 11).

Acaba gerando uma falsa impressão que a cidade grande é melhor (ZL, p. 151).

Este aluno, entretanto, concorda com a mídia televisiva:

"É difícil, visse! (sic). Mas acho que é verdadeira essa imagem que ela [a telenovela] passa sobre o campo" (RO, p. 171).

Alguns estudantes criticam a telenovela Malhação pela maneira como apresenta o campo para os jovens que estão em processo de formação profissional em escolas agrotécnicas:

Porque você não vê muita divulgação na televisão para o meio rural, você só vê cidade. Malhação mesmo é totalmente urbano [...] (DA, p. 138-139).

Eu acho um erro (ZL, p. 150).

Esse outro é mais categórico na sua afirmação:

"Tem seus prós e contras, mas, em caso de juventude, a cidade grande tem mais oportunidade de profissionalização [...]. Em questão de profissionalização, é na cidade" (LU, p. 158-159).

11. FARO, J. S. Apresentação. In: CALLOU, Ângelo Brás Fernandes (Org.) Comunicação rural e o novo espaço agrário. São Paulo: Intercom, 1999 (Coleção GT's Intercom, n. 8).

12. SILVA PIRES, Maria Luiza Lins e. A (re)significação da extensão rural a partir da ótica de inclusão: a via cooperativa em debate. In: TAVARES DE LIMA, J. R. et al (Orgs.) Extensão rural e desenvolvimento sustentável. Recife: Bagaço, 2003.

13. KOLLING, E. J.; CERIOLI, P. R.; CALDART, R. S. (Orgs.). Educação do campo: identidades e políticas públicas. BrasíliaDF: Articulação Nacional por uma Educação do Campo, 2002. (Coleção Por Uma Educação do Campo, n. 4). 
Em se tratando das escolas do campo, a telenovela Malhação é enfática e incisiva, através de seus personagens, avaliando-as como sendo de nível fraco e prevendo, para quem precisa estudar lá, um futuro sem possibilidades de melhoria. Esse discurso encontra ressonância em alguns dos estudantes, quando afirmam:

Com certeza, principalmente as escolas públicas... eu sou, assim, exemplo vivo, porque sempre estudei no interior, em Paudalho, e o ensino é péssimo! (MP, p. 169-170).

Eu tenho parente no interior e é muito difícil de estudar; principalmente quem mora em sítio, vai ter que se deslocar (DU, p. 150-151).

No que se refere a alguma influência que esse discurso negativo, sobre o rural, possa exercer nas suas escolhas profissionais, os estudantes parecem firmes no seu propósito:

Para mim, não influencia muito, não, porque eu quero mesmo, quero botar em prática (no interior) tudo que aprendi aqui (na escola) (MA, p. 181).

A forma como eles colocaram ali, eles induziram, né? Sendo mesmo do interior, não vai sair nada, mas, como a gente tem uma idéia formada, já sabe que nem tudo que tem ali é verdade (JU, p. 181).

A leitura, realizada pelos estudantes, de valores como honestidade, verdade, amizade e confiança da personagem Luíza, considerando suas experiências pessoais e sua relação com o mundo globalizado, distancia-se das mensagens apresentadas no vídeo:

Eu acho que é muito difícil ter uma menina como ela assim, certinha, como Luíza (BA, p. 2).

Inocente demais... Dentro da novela, para ser verdade... infantil demais na novela (RO, p. 35).

Já as mentiras da personagem Carla, a imaturidade e indecisão de Cabeção, mesmo percebidos como negativos, são valores que parecem ocupar mais espaços nas vivências individuais:

Eu acho que tem... para chegar ao ponto que ela faz, eu acho que existe (PR, p. 12).

Eu acho que tem [...] eu acho que o mundo tá tão modificado; eu acho que tem muitas meninas malvadas que fazem o mal (DA, p. 12).

Todo mundo tem essa parte de Cabeção (AD, p. 14).

Sobre a influência que os personagens de Malhação podem exercer no comportamento dos estudantes com relação a amigos, namoro, família, situação financeira ou liberdade, este estudante foi categórico ao afirmar:

A gente nunca se entende com um personagem totalmente; a gente se entende por parte, não é? Ou seja, eu queria ser esse aqui, com mais esse, com mais esse aqui, sem isso e sem aquilo, sem a cabeça, sem o pescoço... (RO, p. 206). 


\section{Outro aluno afirmou:}

Dá vontade de estudar num colégio daquele, num grupo daquele... cada vez tem uma fase $[\ldots]$ a pessoa está olhando e pensa: "Pô! Era massa que tal lugar fosse assim" (JA, p. 97).

\section{A AVALIAÇÃO DA TELENOVELA MALHAÇÃO}

Na compreensão dos estudantes, o cotidiano ficcional da telenovela se distancia do cotidiano real deles, uma vez que Malhação não apresenta as dificuldades financeiras dos personagens:

Só mostra assim que eles estão cheios de dinheiro, comendo [...] sempre com roupa boa e da moda, e nenhum sofrimento nessa parte; é iludindo o jovem... só querem farrear; têm carro, casa... (DU, p. 16).

Nela, as classes menos abastadas são mostradas de forma caricaturada:

Tem uma coisa também que é interessante: é que, na Malhação, não tem nenhuma pessoa da nossa condição social. As pessoas lá não são pobres, não; todos têm uma condição de vida boa, de boa a ótima. É diferente da realidade mesmo (EE, p. 198).

Além disso, através dos personagens, demonstram-se facilidades quanto a questões como primeiro emprego e relacionamentos sexuais:

É que pra ele, assim, foi muito rápido arrumar um emprego e, na verdade, vocês sabem que não é assim; mas tem jovens que pensam que é assim, e fazem isso que não estão nem aí, que transam com o primeiro namorado, que traem amigas por causa de outro, porque vê a novela e faz (JA, p. 262).

\section{AVALIAÇÃO DA PESQUISA}

Nos depoimentos, os estudantes analisaram a pesquisa da seguinte maneira:

Oportunidade de desenvolver a criticidade de cada um:

"Eu achei, assim, que foi muito produtivo, porque deu a chance de a gente, assim, ver com outros olhos aquilo que a gente constantemente [...] vê na tv... mas ver muitas vezes sem ter o senso crítico, um senso mais avaliador do que se passa" (ZL, p. 23).

Interagir e conhecer melhor as pessoas com quem se convive:

"Foi um momento de escutar também, ver o que os outros pensam, né... saber mais, sei lá, sobre os colegas, meus amigos que nós convivemos (DU, p. 236).

Através das experiências dos outros, mudar suas atitudes: 
comunicação \& educação • Ano XIII • Número 2 - maio/ago 2008

14. OROZCO-GOMEZ,

G. Las mediaciones. La

investigación en comunicación desde la perspec-

tiva cualitativa. México:

Universidad Nacional de

La Plata, 1997.

15. SOUSA, M. W. Recepção e comunicação: a busca do sujeito. In: SOUSA, M. W. (Org.). Sujeito, o lado oculto do receptor. São Paulo: Brasiliense, 1995.
"Pelo menos pra mim foi como uma terapia! [...] que eu não gostei não teve nada, não” (AA, p. 245).

De vencer a timidez de falar em público:

"Eu sou muito tímida, totalmente tímida, e aqui eu perdi a timidez... falo, falo, falo. Eu gostei, gostei muito, achei muito positivo" (JA, p. 264).

\section{CONSIDERAÇÕES FINAIS}

Não se pode ser conclusivo quanto à interferência da telenovela Malhação no processo de formação profissional dos jovens estudantes das escolas agrotécnicas do CODAI, ainda que o discurso da mídia televisiva não pareça estar interessado em fazer aproximações com o cotidiano deles, nem com a agropecuária. Tampouco podemos, com esses dados, alegar generalizações, mesmo porque o número de participantes no estudo é numericamente limitado no vasto universo das escolas agrotécnicas espalhadas tanto na região Nordeste como no Brasil.

Observa-se, ainda, que a telenovela, se não intervém de maneira absoluta no cotidiano dos estudantes, também não passa incólume por essa fase de intensas transformações físicas e psicológicas. De certa forma, ela está contribuindo, ao tentar aproximar dois cotidianos tão distintos, o real e o ficcional, para ratificar a importância dos novos estudos de recepção que, hoje, vislumbram o sujeito-receptor não mais como passivo ante as mensagens da mídia televisiva, uma vez que este está mediatizado, segundo os estudos de Orozco $^{14}$ e Sousa ${ }^{15}$, também pela escola, pela família, pelo bairro, pelos diversos grupos sociais de que participa e pelas suas leituras de mundo.

\section{REFERÊNCIAS BIBLIOGRÁFICAS}

BACCEGA, M. A. Da comunicação à comunicação/educação. Comunicação \& Educação, São Paulo: CCA-ECA-USP/Segmento, ano VII, n. 21, maio/ago. 2001.

CARNEIRO, Maria José. O ideal urbano: campo e cidade no imaginário dos jovens rurais. In: SILVA, Francisco Carlos Teixeira da; SANTOS, Raimundo; CARVALHO COSTA, Luiz Flávio de (Orgs.). Mundo rural e política: ensaios interdisciplinares. Rio de Janeiro: Ed. Campos Pronex, 1999.

ELIAS, M. F. F. O adolescente diante da novela. Comunicação \& Educação, São Paulo: CCA-ECA-USP/Moderna, n. 11, jan./abr. 1998.

FARO, J. S. Apresentação. In: CALLOU, Ângelo Brás Fernandes (Org.). Comunicação Rural e o Novo Espaço Agrário. São Paulo: Intercom, 1999. (Coleção GT's Intercom, n. 8). 
KOLLING, E. J.; CERIOLI, P. R.; CALDART, R. S. (Orgs.). Educação do campo: identidades e políticas públicas. Brasília-DF, 2002. (Coleção Por Uma Educação do Campo, n. 4).

LOPES, M. I. V. (Org.). Telenovela, internacionalização e interculturalidade. São Paulo: Loyola, 2004.

. Televisão: a vida pelo vídeo. São Paulo: Moderna, 1988.

MALCHER, M. A. A memória da telenovela: legitimação e gerenciamento. São Paulo: Alexa Cultural, 2003.

MARCONDES FILHO, C. Televisão. São Paulo: Scipione, 1994.

Televisão: a vida pelo vídeo. São Paulo: Moderna, 1988.

MARTÍN-BARBERO, J. Dos meios às mediações: comunicação, cultura e hegemonia. Rio de Janeiro: UFRJ, 1997.

MAZZIOTTI, N.; FREY-VOR, G. Telenovela e soap opera. Comunicação \& Educação, São Paulo: CCA-ECA-USP/Moderna, n. 6, maio/ago. 1996.

MOTTER, M. L. Telenovela: a arte do cotidiano. Comunicação \& Educação, São Paulo: CCA-ECA-USP/Moderna, n. 13, set./dez. 1998.

Telenovela e educação: um processo interativo. Comunicação \& Educação, São Paulo: CCA-ECA-USP/Segmento, n. 17, jan./abr. 2000.

Ficção e realidade: a construção do cotidiano na telenovela. São Paulo: Alexia Cultural, 2003.

. Mecanismos de renovação do gênero telenovela: empréstimos e doações. In: MORAES, Gilberto. A moderna agropecuária. 2. ed. Porto Alegre: Sagra DCLuzzatto, 1993.

OROZCO-GOMEZ, G. Las mediaciones. La investigación en comunicación desde la perspectiva cualitativa. México: Universidad Nacional de La Plata, 1997.

SILVA PIRES, Maria Luiza Lins e. A (re)significação da extensão rural a partir da ótica de inclusão: a via cooperativa em debate. In: TAVARES DE LIMA, J. R. et al (Orgs.). Extensão rural e desenvolvimento sustentável. Recife: Bagaço, 2003.

SOUSA, M. W. Recepção e comunicação: a busca do sujeito. In: SOUSA, M. W. (Org.). Sujeito, o lado oculto do receptor. São Paulo: Brasiliense, 1995. 


\section{बृत}
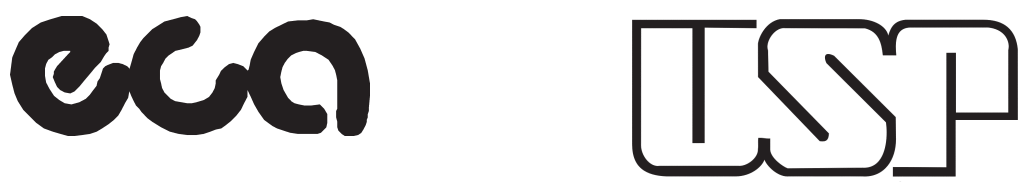

\section{ESPECIALIZAÇÃO LATO SENSU Gestão da Comunicação}

gestor da comunicação planeja e executa projetos de comunicação em empresas privadas, instituições públicas ou movimentos comunitários, nas áreas educacional, empresarial ou artístico-cultural.

- Capacitação do aluno para elaborar, implantar, avaliar e reestruturar projetos de comunicação/cultura.

- Integração teórico-prática da área de comunicação com o mercado de trabalho.

- Formação humanística e profissional sólidas, baseadas na inter-relação comunicação/cultura/artes.

- Qualificação do profissional, preparando-o para compreender o mercado emergente, em constante transformação, e agir sobre ele.
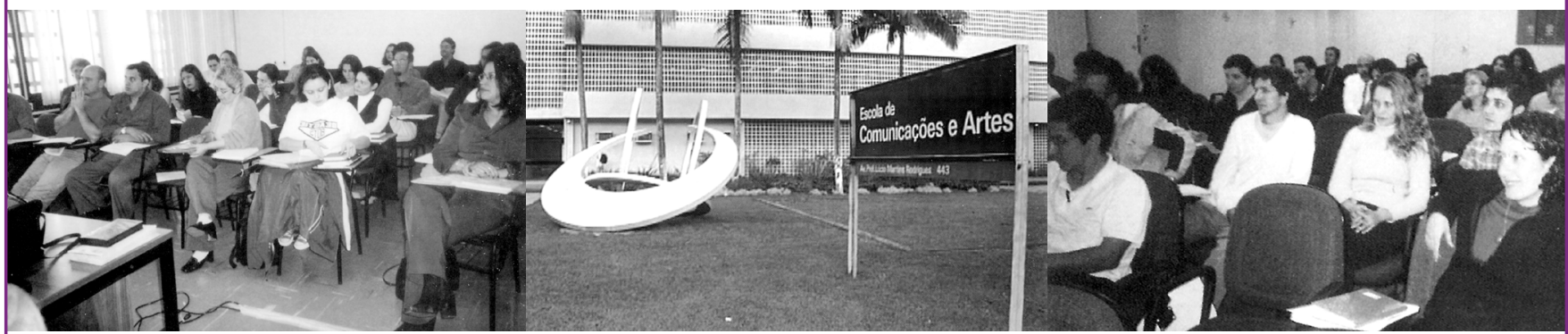

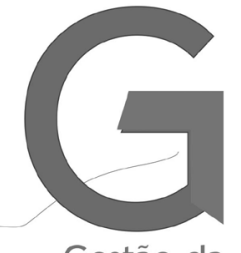

Gestão da Comunicação Especializaçāo lato sensu CCA - ECA - USP
Duração: três semestres

Pré-requisito: formação superior (qualquer área)

Seleção: prova escrita, entrevista e plano de estudo

Ingresso semestral: 1ำ semestre: turma com aulas às sextas-feiras e aos sábados 20 semestre: turma com aulas de segunda a quarta-feira

Informações: ECA/USP: 3091-4063/4341/4326 - e-mail: gestcom@edu.usp.br www.eca.usp.br/gestcom 